\title{
The Prolonged Reform of Taiwan's State-owned Banks (1989-2005)
}

\section{Chia-Feng Leou}

\section{(2) OpenEdition \\ Journals}

Édition électronique

URL : http://journals.openedition.org/chinaperspectives/1343

DOI : 10.4000/chinaperspectives. 1343

ISSN : 1996-4617

Éditeur

Centre d'étude français sur la Chine contemporaine

\section{Édition imprimée}

Date de publication : 15 janvier 2007

ISSN : 2070-3449

Référence électronique

Chia-Feng Leou, «The Prolonged Reform of Taiwan's State-owned Banks (1989-2005) », China

Perspectives [En ligne], 2007/1 | 2007, mis en ligne le 08 avril 2008, consulté le 28 octobre 2019. URL

http://journals.openedition.org/chinaperspectives/1343; DOI : 10.4000/chinaperspectives. 1343 


\title{
Financial Liberalisation and
}

\section{Democratisation:}

\author{
The Prolonged Reform of Taiwan's State-Owned Banks (1989-2005)
}

CHIA-FENG LEOU

Following the global trend of financial liberalisation, Taiwan's government has dedicated itself to its own financial "Big Bang" since the late 1980s. An essential part of this financial overhaul has been the reform of the state-owned banks (SOBs). It was believed that privatisation and deregulation of the SOBs could effectively enhance the efficiency of Taiwan's financial sector. After almost two decades, however, the reform is still not complete. Given its importance, the question arises: why is it taking so long? This article argues that the state has been unable to implement its planned reform policies as its ability to carry out the SOB reform has been significantly constrained by the newly rising political forces resulting from Taiwan's democratisation. This study highlights the new challenges and possibilities of financial governance for the state in Taiwan in an era of democratisation, and could be interesting for future comparative study with other young democracies that also actively undertake financial liberalisation ${ }^{(1)}$.

$\mathrm{T}$ aiwan joined the global trend of financial liberalisation by launching its financial "Big Bang" (2) in the late 1980s. It was hoped that the financial sector could significantly enhance its efficiency and competitiveness by reducing state intervention and allowing market forces to play more important roles. The SOBs, accounting for the bulk of the banking sector and the whole financial system, inevitably became the main target in the "Big Bang". The Kuomintang (KMT, Chinese Nationalist Party) government decided to undertake two principal reform measures - privatisation and deregulation - for the SOBs. Privatisation would mean reducing the government's shareholding in a bank to below $50 \%$. Regulations related to state-owned enterprises (SOE) would no longer apply to these banks ${ }^{(3)}$. In contrast, deregulation of a SOB would mean keeping state ownership of the bank but freeing it from government red tape in areas such as budgets, personnel, auditing and so on. This would only apply to those SOBs that would not be privatised on the grounds of a bank's special "policy mission ${ }^{(4)}$ " or in the event that a bank was experiencing technical difficulties for privatisation.

Supposedly, given their importance, the reform measures should have been undertaken and completed as quickly as possible. But the reality was quite different. Reform of the SOBs has been prolonged, lasting over eighteen years. Why have the reforms been so seriously delayed or why they failed is what this article aims to address. It proposes that the answer lies in the rapidly changing political landscape of Taiwan and in the SOB reform itself. The delayed or failed reforms, in significant part, stem from the fact that the state's ability to control its reform agenda has been constrained by newly rising political forces as a result of Taiwan's rapid democratisation. With a new legitimacy as elected representatives or officials, in the name of checks and balances, politicians have a strong incentive to meddle and self-interest in meddling with the SOB reform policies. To be more specific, the interplay among three key policy players, including the Cabinet (Executive Yuan), the Parliament (Legislative Yuan), and the Taiwan Provincial Government (TPG),

1. This article is a revised version of a paper presented at the Third Conference of the European Association of Taiwan Studies, Paris, 30-31 March 2006. I appreciate the helpful comments from Fiorella Allio, Frank Muyard and another, anonymous, referee.

2. The term initially referred to the liberalisation in 1986 of the London Stock Exchange (LSE) and the following financial liberalisation measures adopted by the Conservative government in the UK in the 1980s. Later, when Japan pursued largescale financial reform in 1998, it used the same term. Since Taiwan conducted large-scale financial reform in 1989, I will also use the term here. See also Lee, Lawrence L.C, "The development of banking in Taiwan: the historical impact on future challenges," Occasional Papers/Reprints Series in Contemporary Asian Studies, $n^{\circ}$ 6, School of Law, University of Maryland, 1998.

3. However, the government would still be able to control the bank to some extent as long as it held onto a significant part of the shares. (It is only after the government sells all of its shares in a bank that the bank becomes wholly private.)

4. For example, some SOBs are asked to provide cheap credit to target industries. 


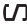

with its Assembly (TPA), before they were downsized in $1998^{(5)}$, have together decisively shaped the pace and content of SOB reform.

This article is in five sections. A review of the origins of the $\mathrm{SOB}$ reform presents the issue in its initial context. Attention is then drawn to the original SOB reform plans formulated by the KMT government at the beginning of Taiwan's financial "Big Bang" in the late 1980s. The rationale behind the policy designs will be explored, providing a foundation against which later changes in the reform can be seen. Parts three and four will highlight the impact of intervention from other political forces outside the Executive Yuan, the main body of the central government and the state apparatus, in two main reform areas: privatisation and deregulation. In these two parts, we will see why, in addition to the Executive Yuan, the Legislative Yuan and the Taiwan Provincial Government, as well as its Assembly, were key players, and how their interplay affected SOB reform throughout the 1990s. The final section sheds light on developments in SOB reform under the new Democratic Progressive Party (DPP) government since 2000. How this first change in ruling parties may have changed the nature of the issue will be considered. That is, as Taiwan's democratisation moves to a new level, has this significantly altered the way in which the SOB reform is to be addressed? In conclusion, the article looks at the implications of the reform for financial governance in Taiwan, and the challenges ahead for the reform as well as what this can contribute to any comparative study with other emerging democracies that also undertake aggressive state banking reforms.

\section{Origins of the reform (the late 1980s)}

The origins of $\mathrm{SOB}$ reform in Taiwan involve unprecedented challenges that the authoritarian KMT government faced on both the domestic and external fronts in the second half of the 1980s. Externally, due to the massive trade surplus that Taiwan enjoyed with the United States in the 1970s and 1980s, the United States forced Taiwan to take measures necessary to improve the trade imbalance with threats of unilateral retaliatory measures authorised by the US "Super 301" (). The so-called "necessary measures" could be divided into three parts, the first being to ask Taiwan to import more goods from the United States by either reducing its tariffs or undertaking special procurements for US products. The second was to ask Taiwan to open its do- mestic market to US companies. The third was to ask Taiwan to significantly appreciate its currency against the US dollar. As the United States was Taiwan's most important export market and closest ally in East Asia, Taiwan had little choice but to accept the majority of these requirements. The second and third parts of these concessions had far reaching consequences for Taiwan's financial markets. Firstly, the introduction of new financial institutions from the United States posed a threat to the survival of local players, most of which were under state control. Secondly, the massive and dramatic appreciation of Taiwan's currency, the New Taiwan Dollar (NTD), led to financial chaos as the KMT government allowed the NTD to appreciate almost 40\% from NTD40 : US $\$ 1$ in 1986 to NTD25 : US\$1 in 1989. The huge trade surplus in addition to the surge of "hot money" from abroad seeking profits from the appreciation of the New Taiwan Dollar created an excessive supply of local money, leading to an economic bubble.

The effects of the economic bubble were fast to emerge on the domestic front. At the peak of the bubble, the enthusiastic participation of the public in speculative investment in stocks, property, illegal investment companies as well as underground lotteries, etc., could be felt almost everywhere. Thus, the threat of the bubble bursting and its potentially disastrous social consequences forced the KMT government to seek effective financial solutions.

Even worse for the KMT government were the boiling democratic movements that were a serious challenge to the legitimacy of its rule at the same time. One of the main challenges was aimed at the KMT's party-state business empire. The DPP, the first opposition party established in 1986, and other anti-KMT forces fiercely accused the KMT of exploiting its status as the ruling party by using the SOEs to promote its own business. Besides this, the low efficiency and monopoly of the SOEs, which occupied a significant part of the economy in upstream industries and utility facilities, as well as public transportation, were also under heavy attack. Demands to swiftly privatise most SOEs and return

5. Taiwan previously had a redundant multi-tier government structure. From 1946 to 1998 under the central government, which is located in the national capital Taipei, a Taiwan province government had charge of all "local" affairs on a territory scale that covered almost the whole nation. The system was maintained to support the central government's claim on the whole of China after the KMT lost the civil war and fled to Taiwan in 1949. The TPG and TPA were maintained with real function until 1998. A constitutional reform in 1997 passed under the co-operation between the DPP and KMT, decided to downsize them to empty shells to streamline the government structure.

6. "Super 301" is the section of the US Trade Act that empowers the US Trade Representative to investigate US trade partners to establish whether or not they apply fair and open access to US exporters. 
the KMT's "suspiciously acquired" assets ${ }^{(7)}$ back to the people were building momentum by gaining increasing support from the public. Thus, the political side reinforced the pressure for genuine and comprehensive economic reform as the KMT was desperate to boost its legitimacy.

Under such circumstances, the KMT government decided to push for economic liberalisation on an unprecedented scope and scale. Not surprisingly, the SOEs and the SOBs became prime targets for liberalisation. Two key measures of economic liberalisation were set in motion in 1989. The first was to set up a cabinet-level task force, the SOE Privatisation Committee (SOEPC), in pursuing the privatisation of the SOEs. Shortly after the SOEPC was set up, 20 SOEs were chosen on the first list for privatisation, among which eight were financial institutions. The second was aimed exclusively at the financial sector. By significantly revising the Banking Law, Taiwan's version of "Big Bang" was unveiled. Apart from scrapping controls on bank interest on deposits and loans, the new Banking Law increased the penalties for financial crime, strengthened the banks' capacity to manage risk and allowed the establishment of new private commercial banks, which had been banned for decades ${ }^{(8)}$. Although this policy did not directly involved the SOBs, the inevitable competitive pressure brought in by the new private players in the following years deepened the sense of crisis of the current major players - the SOBs.

\section{Plan and rationale of the reform}

If we look at what has happened in $\mathrm{SOB}$ privatisation in recent years, we might think that privatisation of the majority of SOBs has been a consistent policy since the late 1980s. But this is not the whole picture. At least, under the KMT rule before 2000, privatisation of the SOBs was, in fact, just one part of the SOB reform. As mentioned, two crucial reform methods were initially adopted: privatisation and deregulation. For the former, it was believed that a number of SOBs could get round SOE regulations by becoming "private" banks and thus could compete with private players on level ground. For the latter, while recognising the efficiency that would be brought by privatisation to some SOBs, the government also sought to enhance the operational autonomy of the rest of SOBs by taking this alternative route. Plans were made to draft a new act, Regulations Governing State-Run Financial Institutions (RGSFI), to push for deregulation of the SOBs. The government argued that for some $\mathrm{SOBs}$ it was not state ownership that hindered their competitiveness, rather it was the excessive government regulations. If the new act could be brought in, similar positive effects as privatisation could take place. The difference was that with the new act the government could still maintain a proportion of its banks as government-owned without worrying that they would lose their competitive strength. "Stateowned but run as though privately-owned" was the slogan that the KMT used to illustrate the spirit of the new act. The former minister of finance Paul Chiu ${ }^{(9)}$ recalled why there was a need for this dual approach in a reply to legislators during question time in the Legislative Yuan in 1999:

(...) Despite their enormous contributions to our national economy over the past decades, the state-run financial institutions $(S F I s)^{(10)}$ have been under immense pressure from competition from the newly established private financial institutions from abroad and at home due to the active opening-up of Taiwan's financial markets by the government in recent years. (...) Nevertheless, constrained by the existing government regulations on their personnel, budgets and audits, the SFIs have experienced difficulties in improving their operational efficiency and have become vulnerable to the strong and growing challenges from new rivals. Thus, on the one hand, we have been pushing the privatisation of some SFIs; on the other hand, for those SFIs that are bearing policy missions or won't be privatised in the near future, we will enact the RGSFI [to allow them to gain operational autonomy and efficiency in another way $]^{(\text {II) }}$.

In his later response to questions from legislators, $\mathrm{Mr}$ Chiu gave an example of banks with policy missions. He said that the government-owned Export-Import Bank of the Republic of China would not be privatised because it had special functions to facilitate export and import trade of Taiwan ${ }^{(12)}$. $\mathrm{He}$ went on to say that it would take time for some SOBs to be privatised because they had first to be restructured and reg-

7. When the KMT government took control of Taiwan in 1945 after Japan was defeated in World War II, it took over many assets belonging to either the Japanese colonial government or citizens. In the age of KMT party-state rule, a significant part of this property became privately-owned by the KMT itself, planting the seed for the future controversy about the legitimacy of the KMT's assets. The dispute continues today.

8. See the details of the revised Banking Law in the report of Ministry of Finance to the Legislative Yuan in Lifayuan Gongbao (Parliament Minutes), vol. 78, n 50, pp. 28-31, 1989.

9. In post from 1996 to 2000.

10. Sometimes, the government uses the term SFI rather than SOB as the former includes other SFIs such as insurance firms and investment companies. As banks account for the larger part of SFIs, SOBs and SFIs are almost interchangeable terms in Taiwan's context. In this paper I treat them as the same.

11. Lifayuan Gongbao (Parliament Minutes), vol. 88, $n^{\circ} 33$, p. 193, 1999

12. Normally this was done through offering export credit insurance, re-lending, and other forms of financing facilities. 
U

istered again as corporations; when ready, they would be transferred to private bank status as well ${ }^{(13)}$.

The KMT held formal and full control of state power through the 1990s at the executive and legislative levels. Ultimately, the KMT government failed to deliver these SOB reform policies as it initially planned. In SOB privatisation, it completed only a small number after 1997. In SOB deregulation, the expected RGSFI act was never passed. The delays and failures are explained below.

\section{The delay of SOB privatisation in the KMT era (the 1990s)}

\section{SOB privatisation and democratisation}

As mentioned earlier, $\mathrm{SOB}$ privatisation was initiated in the wider context of all SOE privatisation in 1989. Thus, the $\mathrm{SOB}$ privatisation process was intended to be alongside that of all SOEs. After announcing its broad direction and plan for the SOE privatisation, the Executive Yuan took its first step to implement its agenda in detail providing a legal framework for the SOE transformation. It proposed to revise the existing "Statute of Privatisation of Government-Owned Enterprises" (SPGOE) as the fundamental law for SOE privatisation. The purposes of the statute are made clear in the first two articles:

This Statute is enacted to facilitate the privatisation of government-owned enterprises, to exert the market mechanism, and to enhance the operational efficiency of enterprises (Article 1). The privatisation of government-owned enterprises, either in whole or in part, shall be governed by this Statute... (Article 2) ${ }^{(14)}$ Shortly after the statute was approved by the Legislative Yuan in 1991, the Executive Yuan rushed to promulgate the "Enforcement Rules of Statute of Privatisation of Government-Owned Enterprises" in 1992, to guide involved parties of government agencies, SOEs and their employees in the application of the SPGOE. The next step, as planned, after the legal foundation for the SOE privatisation was in place, was for the Legislative Yuan to review the budget and plan for individual SOE privatisation as submitted by the Executive Yuan.

As far as SOB privatisation was concerned, five banks were the focus of the debate before the late 1990s: First, Hua Nan, Chang Hwa, Farmers and Chiao Tung ${ }^{(15)}$, as the third column of table 1 shows. The first three were under Taiwan Provincial Government (TPG) control and the two remaining were under the central government.

It is not clear why the central government targeted these
TPG-controlled banks first. With hindsight, it might be for the following reasons. First, in terms of business nature, although the three TPG-controlled banks were governmentowned, their banking business was basically commercially-oriented with few specific policy missions imposed by the government. Second, the government held less than $60 \%$ of shares in two of the three banks, making them relatively more easy to privatise (i.e., reduction of government share to below $50 \%$ ). Also, because these banks were holding each other's shares to a certain degree, they would be linked in a change of share structure if any one of them proceeded with privatisation. Third, they were all flagship SOBs in terms of their ranking in assets and market share in lending. If they could be successfully privatised first, the remaining $\mathrm{SOB}$ sould be easier to address having these three as a precedent.

Whatever the reasons, the central government's efforts experienced serious setbacks from the outset. As soon as the central government unveiled the list, the Taiwan Provincial Assembly (TPA) passed a crucial resolution in November 1989 that dampened the central government's hope for a fast solution. The resolution required that the TPG shares in the three big provincial banks should be maintained at or above $51 \%{ }^{(16)}$. In other words, it was impossible to privatise these banks under this resolution as the TPG would always hold more than half the shares in each. The resolution, which was in place until May 1997, was the biggest obstacle to the central government speeding up SOB privatisation. The main causes of this prolonged block are analysed below. Historically, the TPG had enormous power over the banks under its authority despite all these banks being also subject by law to the supervision of the central government. The central government barely intervened in the TPG's affairs in this area due to the TPG's special status and role in Taiwan's politics. The TPG's jurisdiction was almost totally overlapped with that of the central government except for Taipei, Kaohsiung and a number of tiny islands surrounding Taiwan, and the autonomy of the TPG was safeguarded by Taiwan's Constitution at that time. In the face of such a siz-

13. Lifayuan Gongbao, op. cit., p. 197

14. The full texts of these two articles and of the SPGOE are available on the website of the Council for Economic Planning and Development (CEPD) at http://www.cepd.gov.tw/business/business sec2.jsp?linkid=191\&parentLinkID=3 (date of access: 18 March 2006)

15. Why the Taiwan Business Bank was not mentioned in the public debate about SOB privatisation is not clear as it was on the list for the first wave of SOB privatisation. A possible reason is its small size relative to its assets compared to the other three big provincial banks.

16. It was a bipartisan resolution. The KMT's attempt to stop its members from voting for the resolution failed in the end. See Zhongguo Shibao, 25 October 1994. 
Table 1. Progress of privatisation of state-owned banks in the 1990s

\begin{tabular}{|c|c|c|c|c|}
\hline Bank Names & $\begin{array}{l}\text { Controlled by } \\
\text { which authority }\end{array}$ & $\begin{array}{l}\text { Year of proposal } \\
\text { for privatisation }\end{array}$ & $\begin{array}{l}\text { Planned year } \\
\text { for completing } \\
\text { privatisation }\end{array}$ & $\begin{array}{c}\text { Year of } \\
\text { privatisation }\end{array}$ \\
\hline First Commercial Bank & TPG * & 1989 & n/a & 1998 \\
\hline Hua Nan Commercial Bank & TPG & 1989 & $\mathrm{n} / \mathrm{a}$ & 1998 \\
\hline Chang Hwa Commercial Bank & TPG & 1989 & $n / a$ & 1998 \\
\hline Taiwan Business Bank & TPG & 1989 & n/a & 1998 \\
\hline Farmers Bank of China & $\mathrm{CG}^{* *}$ & 1992 & 1996 & 1999 \\
\hline Chiao Tung Bank & CG & 1994 & 1997 & 1999 \\
\hline Taipei Bank & $\begin{array}{l}\text { Taipei } \\
\text { City }\end{array}$ & n/a & $n / a$ & 1999 \\
\hline Bank of Kaohsiung & $\begin{array}{l}\text { Kaohsiung } \\
\text { City }\end{array}$ & n/a & $n / a$ & 1999 \\
\hline Taiwan Cooperative Bank & TPG & \multirow{4}{*}{\multicolumn{3}{|c|}{$\begin{array}{l}\text { These banks were not planned to be privatised soon. } \\
\text { The new drafted act RGSFI would apply to them before privatisation. }\end{array}$}} \\
\hline Land Bank of Taiwan & TPG & & & \\
\hline Bank of Taiwan & TPG & & & \\
\hline Central Trust of China & CG & & & \\
\hline
\end{tabular}

*TPG: the Taiwan Provincial Government; ${ }^{* *} \mathrm{CG}$ : the Central Government — Source: The author's own collection from newspapers and parliament minutes

able provincial government, the central government had to respect the autonomy of the governance of the TPG. In addition, before 1992 the TPA was the only high-level legislature where all members were all directly elected by their constituents in Taiwan ${ }^{(17)}$. The TGA was used as a showcase for the KMT government to demonstrate to the international community that Taiwan had democracy at a time when Taiwan was still under martial law and with limited democracy. As a result, the power of the TPA was recognised for issues under its supervision ${ }^{(18)}$. Furthermore, prior to 1994, while all the TPG governors were appointed by the central government, they needed TPA approval to confirm their nomination. The power of the TPA could not be underestimated by the central government. Against this backdrop, when the central government took initiatives to firstly privatise three SOBs under the authority of the TPG and TPA, instead of forcing the TPG and TPA to accept its decision, it needed to "convince" them.
Apart from the tricky central/provincial government relationships, the new political landscape as a result of Taiwan's rapid democratisation since the mid-1980s reinforced the influence of the TPG and TPA. Taiwan's democratisation moved to a new stage in the late 1980s after the DPP, the first opposition party, was founded in 1986 and Martial Law was lifted in 1987. In appearance, the KMT was still dominant everywhere, but the importance and influence of elected officials and representatives were surging as people expected them to play a more significant role in a new democratic era. As a result, those newly elected officials and lawmakers started to challenge more often the decisions or or-

17. The Taipei City Council and Kaohsiung City Council also enjoyed the same status but their constituencies were small in comparison with the TPA.

18. Because of this special status, many current heavy political figures in Taiwan began to build their political reputations as members of the TPA. The incumbent Premier Su Tseng-chang and his predecessor Yu Shyi-kun are all good examples. 


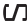

ders from the central government or their parties to reflect the concerns and interests of their constituents.

The long-upheld TPA resolution of 1989 was one of the typical examples. The resolution was passed because the TPA members claimed that they were worried the rights and benefits of the current employees in the three TPG-controlled banks would not be well-protected after privatisation, especially when they found that related laws for privatisation were not in place ${ }^{(19)}$. While it was true that those laws were not in place until 1992, the TPA members' lasting opposition to the privatisation until 1997 implied other reasons.

Most of all, these banks were convenient tools for TPA members. With these banks, TPA members could obtain cheap loans for themselves or their cronies even when lacking sufficient collateral security to back them up. They could even force the banks to purchase their branch offices in a specific location with a much higher price, just because those office buildings belonged to the cronies of some TPA members. Some TPA members held shares in these banks and engaged in insider trading on the stock market ${ }^{(20)}$. This was all because, in the name of supervision, the TPA could essentially control "their" banks. For example, they could decide who would be promoted in the TPG-controlled banks and the budget these banks could be granted at annual reviews.

The TPG was also negative on the issue of privatising its banks. The TPG never openly revealed its opposition to the privatisation but consistently used the TPA resolution to defend itself. Actually, in its own first privatisation plan unveiled in 1995, the three banks were not even mentioned in the plan at all ${ }^{(21)}$. The fundamental reason for this negative attitude was fiscal problems that the TPG faced. The first directly elected TPG governor James Soong had even openly accused the central government of concentrating tax incomes on its own hand regardless of the fiscal difficulty of his government and constituents ${ }^{(22)}$. Given that the three banks' revenues were important sources of annual fiscal income to the TPG, especially at a time when the TPG was in serious debt, the TPG was not about to easily let privatisation proceed soon ${ }^{(23)}$.

The blocking by the Legislative Yuan of the two central government-controlled SOBs took place in a similar way though for slightly different reasons after a new parliament was created in 1992. Under the strong protest of the public who opposed the continuing existence of "permanent ${ }^{(24)}$ " national representatives in the Legislative Yuan and National Assembly ${ }^{(25)}$ for decades, the KMT undertook political reform through sending a petition to the Constitutional Court of the
Judicial Yuan for interpretation regarding the qualifications of those representatives. Consequently, the interpretation ${ }^{(26)}$ disqualified those representatives in 1991, and Taiwan's first parliament where the lawmakers were completely and directly elected by their constituents was created in $1992^{(27)}$. The new Legislative Yuan immediately seized centre-stage. The newly elected lawmakers were all keen to voice their opinions on public policies considering the public was constantly watching their performance, which would affect their chance of getting re-elected at the next election.

The central government initiated its privatisation plans for the Farmers Bank and Chiao Tung Bank in 1992 and 1994 respectively. While it was not very clear why these two central government-controlled banks were chosen to be privatised first, based on the way the government handled SOB privatisation at that time, by releasing its shares in the stock market, it might have been because these two banks were listed corporations and would find it easier to sell their shares quickly. Whatever the reasons, the KMT government initially assumed these two banks were qualified for privatisation and would be processed efficiently. Unfortunately, most lawmakers had different views on the issue and the Executive Yuan had difficulty in convincing them until 1998. Although most lawmakers agreed with the direction to privatise the two banks, they expressed their main concerns time and time again:

These two banks all had special policy missions. Farmers Bank was for the farming industry; Chiao Tung Bank was for mid- or long-term development of targeted industries. If they were privatised, would they continue these missions ${ }^{(28)}$ ?

19. Gongshang Shibao, 15 May 1997.

20. Zhongshi Wanbao, 15 March 1997.

21. Zhongguo Shibao, 14 September 1995.

22. Gongshang Shibao, 17 March 1997.

23. While the TPG could benefit from immediate sale of its shares, it would lose its annual income from these banks in the future.

24. Permanent because they were elected in mainland China before the KMT completely retreated to Taiwan in 1949. The KMT used to use these representatives to bolster its claim over mainland China. These permanent representatives stayed in post for more than forty years until 1991

25. This was Taiwan's second parliament which was mainly in charge of constitutional amendments and electing the president and vice president before 1996. It was abolished in June 2005

26. Interpretation $\mathrm{n}^{\circ} 261$, full text available at: http://www.judicial.gov.tw/constitutionalcourt/EN/p03_01.asp?expno=261 (date of access: 20 March 2006)

27. Before 1992, when some permanent representatives died, the KMT allowed replacements who were elected by people in Taiwan to fill vacant positions. 
Some precedents showed that SOE privatisation would transfer shares from the government to a number of private conglomerates, putting public interests at risk. The two SOBs might end up in the same situation ${ }^{(29)}$.

The government's privatisation policies were not complete while the government only tried to reduce its shareholding to less than $50 \%$. If the government was really serious about giving up its control over the two banks, it should sell all its shares. The government was just trying to free the two banks from the supervision of the Legislative Yuan after privatisation ${ }^{(30)}$.

The prices and timing in selling the government's share in the two banks in the stock market were improper. The two banks' shares deserved to fetch a higher price and their release should be undertaken under the condition that it would not affect price levels on the stock market ${ }^{(31)}$.

They argued that before these concerns were properly addressed by the government, the bipartisan decision in the Legislative Yuan was to continue to block the government's privatisation plan for the two banks.

\section{Political reforms broke deadlocks of SOB privatisation}

The aforementioned oppositions from the TPG/TPA and the lawmakers in the new Legislative Yuan notably disappeared in 1997 after President Lee Deng-hui launched new political reforms in 1996 and 1997. After Lee was re-elected as President - for the first time by popular vote - in March 1996, he felt that there was a need for the whole nation to seek a consensus about the development of Taiwan in several key policy areas such as cross-Strait relations, economic development and constitutional reform. With support from the DPP ${ }^{(32)}$, Lee successfully convened the National Development Conference (NDC) in December 1996 and put the political consensus reached at the NDC into practice by constitutional amendments in July 1997.

The most important result from this series of political reforms regarding $\mathrm{SOB}$ privatisation was the decision to downsize the TPG and TPA by the end of 1998 with almost all their functions and assets including TPG-controlled banks transferred to the central government. In response, the TPA decided to overthrow its 1989 resolution and implement the privatisation of the three TPG-controlled banks ${ }^{(33)}$. Thus, soon after in 1998, all three banks including another smaller bank were privatised as the fifth column of table 3.1 indicates. The success of the reform triggered follow-up repercussions at the Legislative Yuan. On the one hand, the re- form had set a precedent and all involved parties were satisfied with the results ${ }^{(34)}$. On the other, the political climate pushed the Legislative Yuan to react to the privatisation issue. Because one of the resolutions passed in the NDC required that all SOEs should be privatised in five years, though not legally binding, the Legislative Yuan was under pressure to follow this requirement. As a result, Farmers Bank and Chiao Tung Bank all successfully completed privatisation in 1999.

\section{The failed deregulation of the SOBs in the KMT era (the 1990s)}

While $\mathrm{SOB}$ privatisation suffered serious delays throughout the 1990s, the other dimension of SOB reform - deregulation - failed completely in the end. Despite repeated attempts, the KMT government was not able to get the Regulations Governing State-Run Financial Institutions (RGSFI) passed. At least ten versions of the RGSFI were drafted by the KMT since the first formulation of the idea of deregulation in the $1970 \mathrm{~s}^{\left({ }^{(3)}\right)}$. However, according to the study by Lee Yun-san, from the beginning an ongoing dispute among different branches of the central government meant its enactment was doomed ${ }^{(36)}$.

As the draft of the RGSFI was proposed by the Ministry of Finance (MOF) under the Executive Yuan and its purpose was to free SFIs from existing regulations for all civil servants and SOEs, it ran into strong opposition from other related governing Yuan: the Control Yuan, the Examination Yuan and the Legislative Yuan. The Control Yuan had the power to audit government agencies in the use of their budgets in accordance with their original plans and amounts. The Examination Yuan was in charge of recruiting civil servants

\section{Gongshang Shibao, 20 May 1997. \\ 29. Ibid. \\ 30. Gongshang Shibao, 30 June 1994. \\ 31. Zhongguo Shibao, 11 April 1997.}

32. The DPP shared common political goals with Lee. Most important was the downsizing of the TPG and TPA. In addition to their concern for better efficiency and governance, they also wanted to reduce the power of TPG governor James Soong, whose approval rate among the public was extremely high at that time.

33. By controlling the agenda, the TPA could be involved in deciding the banks' share price and the timing for selling the shares on the market.

34. The positive reactions from the employees in the four banks were particularly meaningful.

35. See these versions of different drafts at Gongying Yinhang Quanli Caoan Cankao Ziliao (Collections of the documents related to the drafts of the RGSFI), Taipei: Ministry of Finance, 1991.

36. Lee, Yun-san, "Taiwan Gongyou Jinrong Jigou Quanli zhi Tantao" (On the management of state-owned financial institutions), in Gongying Yinhang Quanli Caoan Cankao Ziliao 


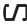

and their promotions and pensions. The Legislative Yuan had the power to review all the budgets and plans of government agencies before they were implemented. Unless the new RGSFI could allow an exception, these Yuan contended that the Executive Yuan would cross power boundaries and create a breach of the Constitution. As a result, the MOF tried to strike a compromise among the Yuan and different versions of the RGSFI were the result. Unfortunately, the difference in views was so great that resolution was difficult.

While this explanation is convincing in a sense, it does not explain why an authoritarian regime like the KMT, before the 1990s, could not co-ordinate different views on this issue. Perhaps the real cause of the delay in putting the RGSFI into practice is that the KMT did not really want it to happen before the financial "Big Bang" of 1989. As the SOBs were still very helpful in promoting industrial policies, excluding largely the participation of private players in the banking sector and maintaining the stability of the financial system, the KMT lacked the incentive and thus the determination to enact the RGSFI $^{(37)}$.

To break the deadlock, a constitutional amendment with regard to the RGSFI was approved by the National Assembly in 1994. The article says:

The state shall manage government-run financial organizations, in accordance with the principles of business administration. The management, personnel, proposed budgets, final budgets, and audits of the said organizations may be specified by law ${ }^{(38)}$.

The passage of the article stemmed from the strong lobby pushed by the Association of Banks when sustainable SOB privatisation was still not in sight and new private commercial banks just entered the banking sector. The $\mathrm{SOB}$ members of the association attempted to strengthen their position in the future market by enacting the RGSFI.

The latest draft of the act was sent to the Legislative Yuan for deliberation in 1997. Once again it did not get through. Firstly the Legislative Yuan was too focused on SOB privatisation that it did not hold a session for discussion of the draft act. Then, when the act was finally discussed in 1999, most lawmakers insisted that there was no need to enact it if the government planned to privatise almost all $\mathrm{SOBs}$ before very long anyway. Also, they argued that, as a number of cases of SOB privatisation were recently completed, all the MOF had to do was to keep doing the job ${ }^{(39)}$.

\section{The SOB reform in the DPP era (2000-2005)}

\section{The DPP's basic stance before 2000}

Before the DPP came to power in 2000, it had an extremely negative attitude towards both the SOEs and the SOBs. In its view, the SOEs were inefficient in the economy and provided special access for profit to the KMT. Taking side with a number of liberal economists ${ }^{(40)}$, the DPP saw the SOEs as a burden, their survival lay not in their competitiveness but in their monopolistic or oligarchic positions in their individual sectors. If they could be privatised and let other private enterprises join the competition, their productivity would pick up and the whole economy would benefit from improved product quality and lower prices spurred by open and fair competition among market competitors. It also denounced the SOEs as channels for political feedback to some high-ranking government officials and military officers after they had retired. Normally, these retired officials and officers would be granted a position as chairman or president in an SOE. What was even worse was that the SOEs were frequently contributing to the growth of the KMT's own business empire by providing massively profitable contracts, an evident symptom of the KMT's abuse of its long-time political rule.

Because of this negative stance, the DPP has upheld privatisation as a tool to dismantle the colossal SOEs and undermine the KMT's economic power base. In the DPP's party platform, the section on economic, fiscal and financial policies briefly outlined these goals: The SOEs have to be privatised and exposed to market competition. In order to get rid of political cronyism and market monopolies, and enhance operational efficiency, this basic principle should be followed. For some SOEs enjoying monopolistic or oligarchic market positions but having difficulties being privatised in the near future, their functions have to be adjusted and put under the careful surveillance of the legislatures ${ }^{(41)}$.

(Collections of the documents related to the drafts of the RGSFI), p. 150, Taipei: Ministry of Finance, 1991. Lee was minister of finance in 2002 for the DPP government.

37. I am indebted to Huang Tien-lin for this argument. Mr Huang used to chair the First Commercial Bank, a top-five SOB, before 2000. He had been a senior economic policy adviser to President Chen Shui-bian from May 2000 to May 2006.

38. Article 10, Item 4, the Additional Articles of the Constitution of the Republic of China, available at http://www.gio.gov.tw/info/news/additional.htm (date of access: 26 August 2005)

39. Lifayuan Gongbao (Parliament Minutes), op.cit., pp. 191-231, 1999.

40. Chen, Shi-meng, Lin, Chong-Cheng, Chu, Jing-yi, Chang, Ching-si, Shih Jun-ji, and Liu, Jin-tian, Jiegou Dangguo Ziben Zhuyi [Disintegrating KMT-State capitalism], Taipei: Taipei Society, 1992. 
Accordingly, the DPP should have shared a common ground with the KMT regarding SOE privatisation since the KMT's announced policies were on the track that the DPP wished. In practice, the DPP was also worried that the KMT might manipulate the process of privatisation for its own benefit. As the KMT was the ruling party, it had easy access to inside information about many projects of the SOE privatisation. In the name of privatisation, the KMT could either let its own business empire acquire some SOEs or instead let its powerful partners, the local business tycoons allied with it, benefit from similar juicy deals. As a consequence, SOE privatisation would not end in a healthier economy but a lasting twisted economic system under the dominance of the KMT business empire and its cronies. Moreover, even after privatisation, the KMT government could still control most former SOEs through controlling the majority on their boards as the biggest shareholders. Under such circumstances, while the "privatised" SOEs were still under the government's control, they were no longer under the monitoring eye of the legislature. Thus, the DPP tended to insist on a "real" privatisation of the SOEs without any interference from the government and the KMT in any way. The DPP's concerns were highlighted and addressed in the National Development Conference (NDC) of 1996 because the KMT needed the support from the DPP to avoid the failure of the conference. Under the demand of the DPP representatives and the widespread support of other participants, the NDC reached two important consensus with regard to SOE privatisation and KMT enterprises:

1. All SOEs have to be privatised in five years.

2. The KMT promises that its enterprises will not take part in investments that are involved with business in monopolistic or oligarchic positions and government projects ${ }^{(42)}$.

Overall, the DPP's stance on SOE privatisation before 2000 was cautious support. It embraced the idea of using privatisation as a means to improve the SOEs in particular and the whole economy in general. But the worry that the KMT might exploit its ruling position to benefit from the process of privatisation made the DPP very careful about it.

\section{Two stages of financial reform under a di- vided government}

After the DPP took power in 2000, the issue of SOB reform was reduced to how much and how fast the rest of the SOBs should be privatised and controlled. Signs have shown that the DPP government has given up the idea of enacting new legislation to deregulate a number of $\mathrm{SOBs}$ since the legislation has had no mention since 2000 and most $\mathrm{SOBs}$ are in line to be privatised shortly. But the issue of SOB reform is no less complicated for the DPP than it was for the KMT before 2000. No sooner than it came to power, the DPP faced a looming non-performing crisis and a significant number of financial institutions were on the verge of insolvency. It had to sort out the crisis before it could continue the SOB reform. Besides this, the issue of "government-run but private-owned" banks needed to be further addressed. As table 1 shows, the KMT actually had privatised eight $\mathrm{SOB}$ s before 2000. But these banks were still run by the government after 2000 because the government still held a high number of their shares ${ }^{(43)}$. Whether the government should keep reducing its shares has caused new debate about the state's role in the banking sector. Furthermore, politics in Taiwan since 2000 makes constructive policy deliberation less likely due to the existence of a divided government. Although the DPP won the presidential elections of 2000 and 2004, the KMT and its ally the People First Party kept control of the Legislative Yuan. The constant confrontation between the opposition "Blue camp" and the ruling party's "Green camp" (composed of the DPP and its ally the Taiwan Solidarity Union) on national identity grounds and other related issues makes politics more polarised than ever. As a result, party discipline has been much more tightened in all political parties in the Legislative Yuan. The former bipartisan opposition to the KMT's Executive Yuan policies has declined. What has occurred more, instead, is that the Blue overthrows, twists or blocks the policies of the Green, putting the DPP government in a difficult ruling position ${ }^{(44)}$.

Nevertheless, as we look back at the DPP's first term in government from 2000 to 2004, unlike its many policies in other areas, the DPP's financial reform policies suffered relatively less from its minority position in the Legislative Yuan. Despite numerous delays on approving essential bills, budgets or plans by the opposition parties, the DPP managed to attain notable credit for its financial reforms. The goal of the first stage of financial reform, initiated by President Chen Shui-bian in August of 2001, the so-called "258 financial reform": to lower non-performing loans ratios to below $5 \%$

41. See the DPP platform, Section 3, Article 7. The original text is in Chinese and available on the DPP website: http://www.dpp.org.tw/ (date of access: 13 August 2005). The author's translation.

42. Zhongguo Shibao, 25 December 1996.

43. As the private share holders were scattered, it was not easy for them to have collective and concerted actions against the control of the government on these banks, even though the percentage of private shares outnumbered in total. 


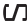

and raise capital adequacy rates to $8 \%$ among domestic banks within two years was achieved on time. Meanwhile, following the passage of the Financial Holding Company Act in 2001, 14 financial holding companies were established from 2001 to 2002. In addition, with regard to speeding up the disposal of seriously troubled financial institutions, the Financial Restructuring Fund was established and has successfully bailed out 47 of these institutions and forced them to drop out of the market through closure or merger. Also, the DPP government has overhauled the financial regulation system by setting up the Financial Supervisory Commission (FSC), an integrated agency aiming at independent supervision and monitoring of the operation of the whole financial system.

With hindsight, two key factors contributed to these betterthan-expected outcomes. First, as a looming banking crisis approached, the opposition parties were under social pressure to co-operate with the DPP on reform bills and measures. Although sometimes they disagreed on some technical matters or worried that the DPP might get too much credit, they did not totally block the DPP from implementing financial reform, especially as it attained strong support from the media and public opinion. Secondly, the convention of the Economic Development Advisory Conference (EDAC) by President Chen in 2001 reinforced the mandate of the DPP reform agenda. The conference took place at a time when Taiwan experienced its worst economic downturn in decades. By inviting representatives from the ruling and opposition parties, scholars, business leaders, and labour unions, President Chen was hoping to use the conference to determine common goals and effective solutions to the unprecedented economic challenges that Taiwan was facing ${ }^{(4)}$. Conference approval offered such strong legitimacy that no political party could oppose the items without good cause.

The conference also sped up SOB privatisation as a consensus reached required that the government-run banks should be entirely privatised ${ }^{(46)}$. The DPP then focused on reducing government share in the "government-run but privateowned" banks.

Based on the policy accomplishments and consensus reached in the first term, in October 2004, President Chen took a further step in consolidating the banking sector by unveiling his goal of "the second stage of financial reform" to halve the number of government-run banks to six by 2005 and the number of financial holding companies to seven by 2006, increase the market share of three domestic banks to above $10 \%{ }^{(47)}$, and encourage one financial institution to be taken over by a foreign counterpart or listed on overseas mar- kets $^{(48)}$. The rationale behind this reform agenda, according to the former Vice Premier Wu Rong-yi, who was commissioned to supervise the banking sector reform in 2005, was to solve the problem of over-banking and strengthen the competitiveness of local players by increasing their scale. The long-term goal of the second stage of financial reform was to have three to five "national champions" banking groups that would together have a market share of over $80 \%$. But as the private players remained wary about merging with their rivals, the DPP government argued that the government-run banks should take the initiative to start the consolidation process by merging with other players ${ }^{(49)}$.

However, the push for the second stage of financial reform in 2005 raised public concerns and surging opposition from the labour unions when government-run banks went up for acquisition by private players. Typical is the failure of the sale of shares in the government-run Taiwan Business Bank. The labour union of the bank was not satisfied with the early-retirement packages for lay-offs as proposed by the private bidder E. Sun Financial Holding Co. After a four-day strike and prolonged negotiations, the bidder dropped its bid $^{(50)}$. Since then, a controversy has arisen around the way the DPP government privatises government-run banks. Some are saying that the government is deliberately selling out its banks to private players at a low price, which not only undermines the public interest but also puts the interest of current bank employees at risk. Against the backdrop of an increasing income gap between rich and poor in Taiwan, the government's rush attempts to sell banks to private conglomerates have been viewed by critics as adding fuel to the fire ${ }^{(5)}$. Seizing this opportunity, opposition parties have vowed to stop the government from pushing ahead the second stage of financial reform, casting more uncertainty on the reform's future. The DPP government ended up encour-

44. The best example is the issue of arms sale deal with the US. As the Bush administration has approved to sell a number of important weapons to Taiwan in 2001, the budget has been constantly blocked by the Blue in the Legislative Yuan.

45. See the background of the conference at a press release from the Presidential Office of Taiwan: "Background for Convening the Economic Development Advisory Conference", available at http://www.president.gov.tw/2 special/economic/e index.html (date of access: 14 August 2005).

46. In the common view of the finance group of the conference, which is available in Chinese at: http://www.president.gov.tw/2_special/economic/index-92.html (date of access: 14 August 2005).

47. The three banks could be privately or publicly-owned and do not rule out the participation of foreign capital. The point is to cultivate national champions of banks and make the banking sector less scattered.

48. Zhongguo Shibao, 21 October 2004.

49. Gongshang Shibao, 6 September 2005.

50. aipei Times, 15 September 2005. 
aging mergers among the banks it ran and reached its deadline to halve the number of government-run banks to six by $2005^{(52)}$

\section{Conclusion}

As this study shows, rapid democratisation over the past two decades in Taiwan does significantly affect how the Taiwanese government addresses SOB reform. Due to rapid democratisation, the government has been forced to accommodate a new political environment where the power of the elected politicians at the provincial level (the TPG/TPA) or at the national level (the Legislative Yuan) has been elevated to such an extent that it puts up constant challenges to policies formulated by the administrative power centre. While the impact of democratisation on SOB reform was more felt in terms of independent behaviour by elected politicians from all political parties in the KMT era, this evolved into a clash between the ruling party and the opposition parties in the DPP era.

Democratisation has had a mixed impact on SOB reform. On the one hand, the government has suffered delay or failure; on the other hand, the accountability of the government is far improved. The prospect of financial governance particularly and economic governance generally in Taiwan will de- pend on whether democracy can further deepen to effect a balance between governing accountability and efficiency.

As far as $\mathrm{SOB}$ reform is concerned, a major challenge is unresolved: the role of government-run banks is not clear. On the one hand, the majority views agree to reduce government intervention in the banking sector, but on the other, as people are also worried that the influential financial groups owned by private players ${ }^{(53)}$ might control the sector and put the public interest at risk, people are expecting the government to play a more forceful role as a counterbalance. If the government keeps selling off its share in the banks it still controls, it will lose a strong leverage against the dominance of big private players from abroad or at home.

In sum, SOB reform in Taiwan is at a crossroads. In a new democratic era, the rapidly changing political landscapes behind the reform and the shifting public opinions on the issue have made it more complicated and controversial. As Taiwan is not alone in undertaking $\mathrm{SOB}$ reform along with democratisation, this case study is just the first step for future comparative studies on the politics of financial reform. Similar patterns, common factors or major differences might be discovered as a result of comparing Taiwan with other young or emerging democracies that also undertake large-scale financial reforms.

51. A social movement group, Fanzi Lianmeng [Alliance of fairness and Justice], is one of the most active critics. See its view on the issue on its website: http://www.justice. org.tw/index.htm

52. The six government-run banks are the First Financial Holding Company (FHC), Hua-Nan FHC, Mega FHC, Bank of Taiwan, Taiwan Cooperative Bank, and Land Bank of Taiwan.

53. In the financial sector, there are three influential family financial groups: the Koo family with Chinatrust FHC $\left(n^{\circ} 7\right)$ and China Development FHC $\left(n^{\circ} 12\right)$, the Wu family with Taishin FHC $\left(n^{\circ} 2\right)$ and Shin Kong FHC $\left(n^{\circ} 8\right)$, and Tsai family with Cathay FHC $\left(n^{\circ} 1\right)$ and Fubon FHC $\left(n^{\circ} 6\right)$. The numbers behind these FHCs are their rankings in terms of total assets among the 14 FHCs in Taiwan. Politically, these families are active in maintaining their relationships with all the main political parties. Their influence is persistent no matter which party is in power. 